\title{
A comparison of bird communities in natural and revegetated grasslands in south Brazil
}

\author{
Rafael Gustavo Becker ${ }^{1,4}$, Gabriela Paise ${ }^{2}$ \& Marco Aurélio Pizo ${ }^{3}$ \\ 1 Programa de Pós-graduação em Diversidade e Manejo da Vida Silvestre, Universidade do Vale do Rio dos Sinos (UNISINOS), São Leopoldo, RS, \\ Brazil. \\ 2 Laboratório de Ecologia de Mamíferos, Departamento de Ciências Biológicas, Universidade Regional do Cariri (URCA), Crato, CE, Brazil. \\ 3 Departamento de Zoologia, Universidade Estadual Paulista (UNESP), Rio Claro, SP, Brazil. \\ 4 Corresponding author: rgbecker@outlook.com
}

Received on 15 October 2018. Accepted on 13 September 2019.

\begin{abstract}
Natural grasslands are declining due to loss, fragmentation and degradation, resulting in the decline of grasslandassociated bird species. The Pampas Biome in south Brazil is not exception to this worldwide trend, facing the expansion of croplands and afforestation with exotic tree plantations for cellulose production. To cope with the continuous degradation and loss of grasslands, restoration is an important conservation strategy, but basic information regarding the response of the fauna to restoration practices in southeastern South America grasslands is lacking. Here we compared the structure of bird communities in natural grasslands and revegetated grasslands after mining by planting native and exotic grasses. We sampled birds using 5 -min point counts with unlimited radius in three replicates of each habitat (natural and revegetated grasslands; average size $22.2 \pm 2.3 \mathrm{ha}$ ). We also compared the vegetation density between the two habitat types. The structure of bird communities at natural and revegetated grasslands differed, with natural grasslands presenting higher species richness ( 42 vs. 35 species) and abundance (1459 vs. 839 records) than revegetated areas, and also a distinct species composition. Ten of the 11 grassland species that were associated to one of the two habitat types occurred more frequently in natural grasslands, which had higher vegetation density than revegetated areas. Even a decade after the beginning of the restoration process, revegetated areas did not resemble natural grasslands in bird species richness, abundance, and composition. These results differed from another study conducted in the Brazilian Pampas in which native plant species were used to actively restore a grassland. Therefore, until we have additional studies addressing the use of exotic grasses for the recovery of bird communities in South America grasslands, we encourage greater representation of native plant species in restoration projects.
\end{abstract}

KEY-WORDS: exotic grasses, habitat restoration, mining, Pampas Biome.

\section{INTRODUCTION}

Recently we saw an upsurge of calls for grassland conservation in face of the many threats to grasslands, including afforestation and invasion by exotic plants (Parr et al. 2014, Bond 2016). In the Pampas Biome of southern Brazil, for instance, approximately $60 \%\left(104,553 \mathrm{~km}^{2}\right)$ of former grassland area had been destroyed by 2002, mostly due to its conversion to arable fields or afforestation with exotic trees (Andrade et al. 2015). This makes the Pampas the second Brazilian biome regarding the relative magnitude of land use changes, getting behind only to the Atlantic Forest (Overbeck et al. 2013).

To confront the continuous degradation and loss of grasslands, or any other vegetation type, ecological restoration is an important strategy. However, research and practice of restoration of tropical grassy biomes has traditionally fallen behind other vegetation types, such as forests (Overbeck et al. 2013). In addition to technical issues for proper grassland restoration (e.g., availability of seeds of native grassland species), basic information regarding the response of the fauna to restoration practices is lacking. Some pending questions about the conservation value of restored grasslands are, for example, threatened animals. Birds, for instance, can be divided into different categories of dependence on grasslands, with grassland-restricted species in general among the most threatened species (Azpiroz \& Blake 2009, Azpiroz et al. 2012): Do such bird species use grasslands restored by planting mostly exotic grasses? In North America we know that grasslands planted mostly with non-native grasses on reclaimed mines supported a community of bird species typical of natural grasslands (Scott et al. 2002).

Here we compared the structure of bird communities in natural grasslands and grasslands revegetated after mining with the planting of native and exotic species. More specifically, we investigated how the species richness, 
abundance and composition of the bird communities at revegetated areas with such a mixture of native and exotic species (but with a predominance of the latter) compare to natural grasslands. Our ultimate goal is to evaluate the efficacy of the restoration procedures currently used by mining companies from the bird's point of view. Such companies follow the Brazilian legislation that permits the use of exotic plant species in restoration (for more details see Normative Instruction ICMBio 2014).

\section{METHODS}

\section{Study areas}

This study was carried out in areas of Companhia Riograndense de Mineração (CRM), at Candiota region in the state of Rio Grande do Sul, south Brazil $\left(31^{\circ} 33^{\prime} \mathrm{S}\right.$; $\left.53^{\circ} 40^{\prime} \mathrm{W}\right)$. This region is largely occupied by openpit coal mining areas, revegetated areas, and natural grasslands (Fig. 1). According to the Köppen (1948) classification, the climate in the area is $C f a$, with cold winter, hot summer, and rainfall distributed over the year but more pronounced between July and October. The average relative humidity is $73 \%$ in summer and $83 \%$ in winter. Average annual rainfall is around $1400 \mathrm{~mm}$.

From 9 to 13 years before this study, active restoration techniques were performed by CRM in which soil from areas that would be mined later was deposited on mined areas after the reconfiguration of the topography.
Fertilizers such as triple superphosphate (NPK) and potassium chloride were added, a mix of mostly exotic (Lolium multiflorum, Urochloa decumbens, Chloris gayana, Cynodon dactylon, Trifolium repens) and one native grass species (Paspalum notatum), were sowed, and again the fertilizer (NPK) and urea were added. Natural grasslands were not actively managed, but were under fire and ungulate grazing, common and part of the evolutionary history of natural Pampas grasslands (Pillar \& Velez 2010). Areas with revegetated and natural grasslands had similar sizes, ranging from 20 to 25 ha.

\section{Bird and vegetation sampling}

We sampled birds from May to December 2006 using 5-min unlimited point counts (Bibby et al. 1992) carried out from early to mid-morning (06:30-10:00 h) and late afternoon (16:00-17:30 h) in three replicates of two habitat types (natural and revegetated grasslands). Only birds seen or heard inside the sampled areas of natural and revegetated grasslands were considered. The average distance between sampling areas was $c .1 .5 \mathrm{~km}$. In each area we sampled eight points distant $200 \mathrm{~m}$ from each other in each season of the year, totaling 32 points per area and 96 per habitat. The locations of sampling points were not fixed but randomized at each season using $\mathrm{xy}$ coordinates (maintaining, however, the $200 \mathrm{~m}$ minimum distance between points). The scientific nomenclature and taxonomic ordering of birds follow Piacentini et al. (2015).

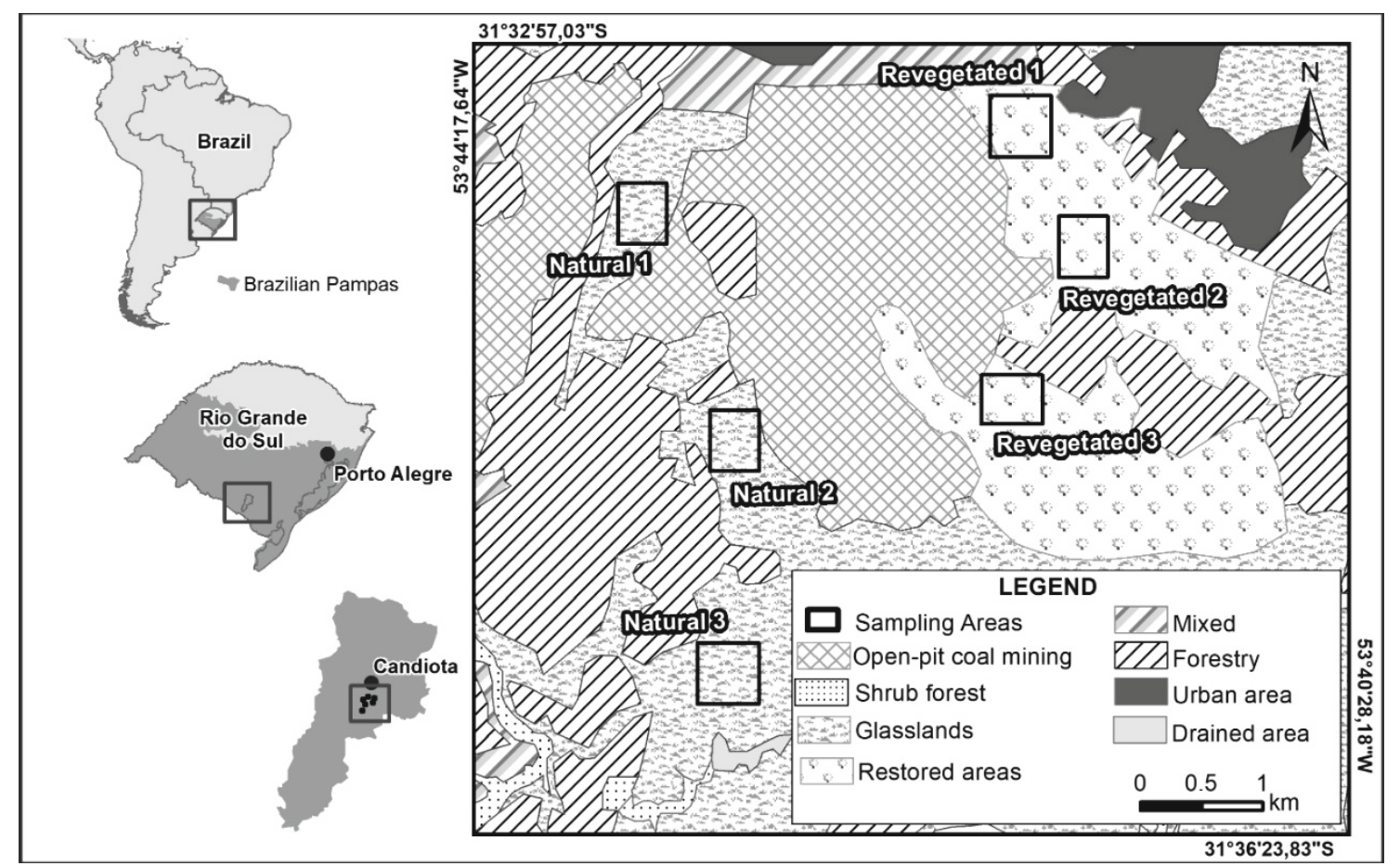

Figure 1. Map of the study site showing the location of the natural and revegetated grassland areas in southern Brazil. 
At each sampling area we set two parallel transects of $150 \mathrm{~m}$ length each and separated $150 \mathrm{~m}$ from each other to assess the vertical structure of the vegetation. At each $5 \mathrm{~m}$ interval we counted the number of times the vegetation touched a $2-\mathrm{m}$ graded rod (maximum height of vegetation) in four height classes (0-50, 51-100, 101150 , and $151-200 \mathrm{~cm}$ ). A quantification of the vertical structure was then given by the density of vegetation at different height classes.

\section{Data analyses}

Bird species richness was compared between natural and revegetated grasslands in two ways. Firstly, we did an analysis of rarefaction based on individuals (i.e., number of records) implemented with EstimateS ${ }^{\circledR}$ version 9.1 (Colwell 2013). This is a non-biased way of comparing the richness of species between areas, as it is not influenced by variations in the density of individuals among areas (Colwell \& Coddington 1994, Krebs 1999, Gotelli \& Colwell 2001). In addition, due to possible spatial dependence among samples, we compared bird species richness and number of records through a hierarchical mixed model test (nested ANOVA) using the function "lme" of the package "nlme" in R software (Oksanen et al. 2011, McDonald 2014). Sampling points were treated as random variables within each fixed treatment (Natural vs. Revegetated).

Following Azpiroz et al. (2012), we classified bird species according to their association to grasslands in southeastern South America in the following categories: (1) grassland-restricted species, i.e., species that do not use alternative habitats, (2) species that extensively use grassland habitats, but other habitats as well, and (3) species that make extensive use of grassland habitats only in certain subregions of the southeast South American grasslands.

We calculated the species diversity for each habitat type using the Shannon-Wienner index $(\log [\mathrm{x}])$ (Magurran 1988). To test if bird species used more frequently any of the two habitats, we performed $G$ tests for the species with 10 or more records. These tests contrasted the frequencies of records at natural and revegetated grasslands with the expected frequencies based on equal number of records at each habitat.

We performed group analysis to test for possible differences in the composition of bird communities between natural and revegetated grasslands using the Multi-Response Permutation Procedures (MRPP) method with Euclidean distances (Zimmerman et al. 1985). This method makes it possible to evaluate the dissimilarity between groups of samples. If the mean dissimilarities of the species composition observed is less than the dissimilarity between randomized groups (999 randomizations) based on the actual distribution of the observed data, the species composition is different. The change-corrected within-group agreement (A) provides and effect size of the dissimilarity between groups, ranging from $<0$ to 1 . The smaller is $A$ the greater the heterogeneity between groups, while if $A=1$ groups are identical. We tested for correlations in the spatial distance (Euclidean distance) and similarity in species composition (Bray-Curtis distance) between the studied areas using a Mantel test (Quinn \& Keough 2002). We performed all these analyses with the "vegan" package in R software (Oksanen et al. 2011, R Core Team 2017).

To test for differences in vegetation density between natural and revegetated grasslands, we used a resampling technique performed with the Resampling Stats ${ }^{\circledR}$ program (Simon 1997, Blank et al. 2001) in which the mean between-habitat difference for each vegetation height class was compared with the mean differences obtained from 10,000 randomizations of the data, accepting as significant observed differences that lied within the 5\% frequency distribution of the randomized differences.

\section{RESULTS}

We made 2298 records (1459 in natural, and 839 in revegetated grasslands) of 49 bird species (21 families, 42 species in natural, and 35 in revegetated grasslands; Appendix I). The cumulative number of bird species stabilized in both habitats, indicating that we sampled most of the species in the studied areas (Fig. 2). Rarefying down the number of records to 800 in both habitats, we got 40 species in natural and 35 species in revegetated grasslands, with non-overlapping confidence intervals indicating different species richness (Fig. 2).

Most species (28 species) were not associated with grasslands, while 13 species make extensive use of grasslands (category 2 of Azpiroz et al. 2012), and 8 species use grasslands only in certain regions (category 3 ).

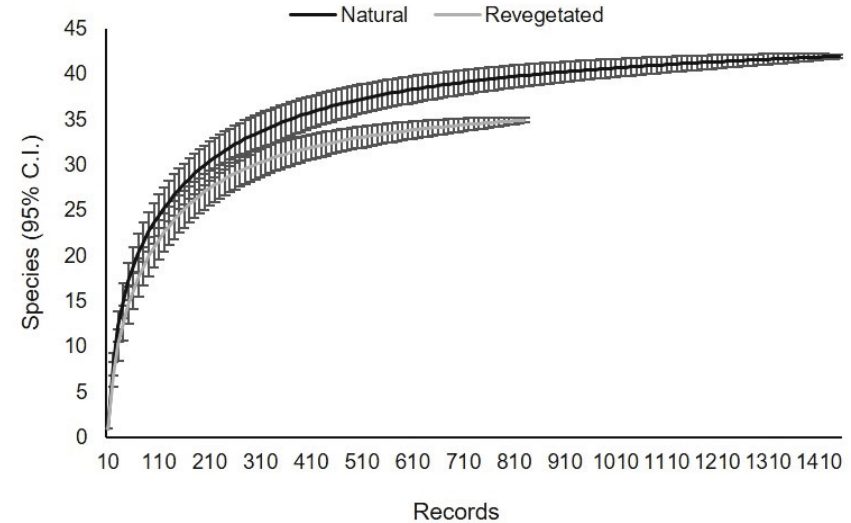

Figure 2. Rarefaction curve based on the number of bird records and their respective confidence intervals (95\%) in natural and revegetated grasslands in southern Brazil. 
No grassland-restricted species (category 1) was recorded (Appendix 1). The representativeness of each category of grassland association did not differ between habitats (G test: $\left.\chi^{2}=1.080, d f=2, P=0.580\right)$. Among the 30 species with 10 or more records, 14 used natural grasslands more frequently than expected by chance, and only Colaptes campestris was associated with revegetated grasslands (Appendix I). Considering only grassland-associated birds (categories 2 and 3), 11 out of 14 species were associated to a habitat type, once again all but $C$. campestris used more frequently natural grasslands (Appendix I).

The species with the highest number of records in both habitats were Zonotrichia capensis, Sicalis luteola, Ammodramus humeralis, and Embernagra platensis, together accounting for $51 \%$ of the total number of records (Appendix I). Natural grasslands had greater diversity than revegetated areas $\left(\mathrm{H}^{\prime}=2.986\right.$ and 2.625, respectively), a difference mirrored by the species richness $(F=6.240, P<0.050)$, and bird abundance $(F=19.508$, $P<0.001$; Fig. 3). Natural and revegetated grasslands also differed in species composition (MRPP: observed delta $=10.45$, expected delta $=10.54, \mathrm{~A}=0.007, P=$ $0.019)$. There was no correlation between the distance separating the studied areas and the pairwise dissimilarity in species composition (Mantel $r=0.198, P=0.374,719$ permutations), indicating that species composition was not related to spatial relationships among areas.

Natural grasslands areas had higher vegetation densities at height classes $0-50 \mathrm{~cm}$ (mean difference $=$ $6.28, P=0.040), 51-100 \mathrm{~cm}(3.43, P=0.001)$, and $101-$ $150 \mathrm{~cm}(4.35, P=0.001)$, but not at $151-200 \mathrm{~cm}(1.41$, $P=0.150)$ in which a few plants were recorded at both habitats (Fig. 4).

\section{DISCUSSION}

The structure of bird communities at natural and revegetated grassland areas differed, with natural grasslands presenting higher species richness and abundance than revegetated areas, and also a distinct species composition. In addition, most of the grasslandassociated birds occurred more frequently at natural grasslands. Differences in vegetation structure between natural and revegetated grasslands is a factor to explain such differences, since the composition of bird communities in southern Brazilian grasslands (and grasslands in other regions; Hovick et al. 2015) is strongly influenced by the spatial heterogeneity of vegetation, that is, by structural changes in vegetation mostly caused in the region by disturbances like fire and grazing (Bencke 2009, Dias et al. 2014). The high sensitivity of birds to vegetation structure was also observed by Fontana $e t$ al. (2016) who found greater species richness of birds in general, and grassland-associated species in particular, in natural grasslands compared to "improved" grasslands, i.e., natural grasslands managed with the addition of fertilizers and exotic species, demonstrating the importance of natural areas for grassland birds (see also Silva et al. 2015).

Together with the lower density of vegetation in revegetated areas, the low number of plant species sowed, most of them exotics, in the restoration process is an additional factor that possibly contributed to the lower diversity of birds in revegetated grasslands. In comparison, natural grasslands are composed by a much diverse plant community (Menezes et al. 2018), which naturally promotes spatial heterogeneity. In the sole comparable study on the recovery of a bird community in actively restored grassland in southeastern South America, Silva (2019) found different composition, but similar bird species richness and abundance between a 3-yr old grassland restored with native plants and a natural grassland area. Limited as the comparison with
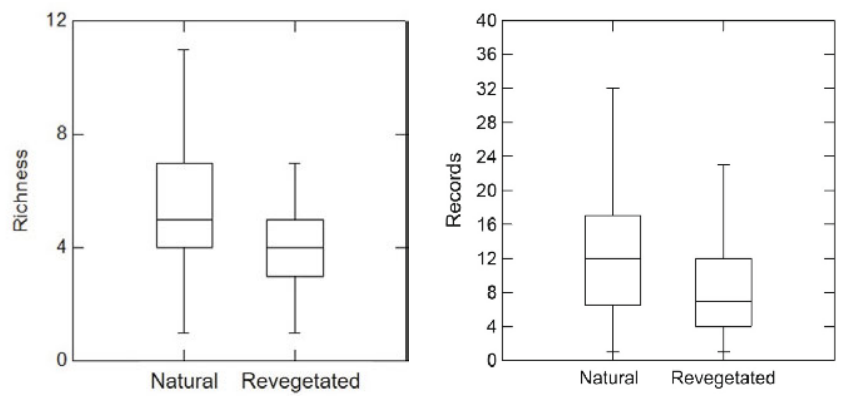

Figure 3. Boxplots showing the median (horizontal line), 25\% - 75\% quartiles (box upper and lower limits), and maximum and minimum values (indicated by the vertical bars) of the species richness and number of birds recorded at natural and revegetated grasslands in southern Brazil.

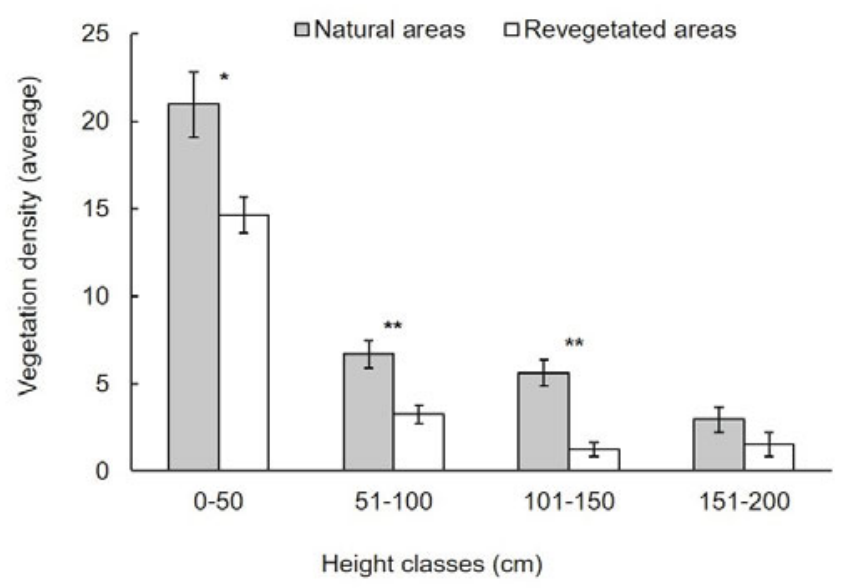

Figure 4. Vegetation density at different height classes in natural and revegetated grasslands as denoted by the number of touches of the vegetation in a $2 \mathrm{~m}$ graded rod. Bars indicate standard errors. Between-habitat differences are indicated by $*(P<0.050)$ and ${ }^{* *}(P<0.010)$. 
this single study might be, we expected similar results for our much older (9-13 years) revegetated areas. That our revegetated areas had smaller bird species richness and abundance than natural grassland areas is indicative that the predominance of exotic grasses in the seed mixtures used in the restoration process is inadequate for the recovery of grassland bird communities. Nonetheless, the species richness we recorded in natural grasslands ( 42 species) is within the range found by Silva $(2019,30$ 46 species), while the richness in our restored sites (35 species) did not greatly differ from her active restoration (30 species).

Apart from the apparent low quality of revegetated areas, the fact that we have not recorded grasslandrestricted birds, that are usually more sensitive to habitat quality (Azpiroz \& Blake 2009), may have to do with the landscape context of our natural and revegetated areas, surrounded by exotic monocultures of grasses (Urochloa sp.) and trees (Pinus sp., Acacia spp., Eucalyptus spp.), agriculture, and extensive livestock farming. However, as restoration of grasslands still faces many technical problems, even the small, isolated grassland remnants remaining are worth conserving (Bond \& Parr 2010). As we shown here, they were preferred over revegetated areas by most grassland-associated birds.

Even though revegetated areas did not represent highquality habitats for several birds, they served as refuges for many species that do not tolerate strongly altered habitats as occur in the matrix surrounding our study areas. What remains to be learned is if revegetated areas offer structural conditions that allow the reproduction of these species, since grassland birds select breeding and nesting habitats with very specific characteristics (Cody 1985). While the reproductive success of birds in North American grasslands recovered after coal mining was comparable to that of natural habitats, indicating that revegetated areas do not necessarily represent reproductive traps for birds (Galligan et al. 2006), the daily survival rates of birds reared in planted grasslands was lower compared to natural grasslands (Fisher \& Davis 2011).

In sum, we found that a decade after the use of predominantly exotic plants to restore grasslands on reclaimed mined areas in the Pampas of south Brazil resulted in a vegetation that was used by several grasslandassociated bird species, but bird species richness, abundance, and composition did not resemble natural grasslands. Our results differed from the only other comparable study conducted in southeastern South America grasslands that, however, used native plant species in the active restoration (Silva 2019). Therefore, until we have additional studies addressing the use of exotic grasses for the recovery of bird communities in the realm of southeastern South America grasslands, we encourage greater representation of native plant species in restoration projects, stimulating policies to overcome the technical difficulties of making available seeds of native species for restoration purposes.

\section{ACKNOWLEDGEMENTS}

We thank the Brazilian Agricultural Research Corporation (EMBRAPA) for financial and logistic support, Cristiano Alves da Silva for preparing the map of the study area, and two anonymous reviewers whose comments greatly improved the paper. M.A.P. receives a research grant from the Brazilian Research Council (CNPq No. 304244/2016-3).

\section{REFERENCES}

Andrade B.O., Koch C., Boldrini I.I., Vélez-Martin E., Hasenack H., Hermann J.M., Kollman J., Pillar V.D. \& Overbeck G.E. 2015. Grassland degradation and restoration: a conceptual framework of stages and thresholds illustrated by southern Brazilian grasslands. Natureza \& Conservação 13: 95-104.

Azpiroz A.B. \& Blake J.G. 2009. Avian assemblages in altered and natural grasslands in the northern Campos of Uruguay. Condor 111: 21-35.

Azpiroz A.B., Isacch J.P., Dias R.A., Di Giacomo A.S., Fontana C.S. \& Palarea C.M. 2012. Ecology and conservation of grassland birds in southeastern South America: a review. Journal of Field Ornithology 83: 217-246.

Bencke G.A. 2009. Diversidade e conservação da fauna nos campos do sul do Brasil, p. 97-117. In: Pillar V.P., Müller S.C., Castilhos Z.M.S., Jacques A.V.Á. (eds.). Campos Sulinos: conservação e uso sustentável da biodiversidade. Brasília: Ministério do Meio Ambiente.

Bibby C.J., Burges N.D. \& Hill D.A. 1992. Bird census techniques. London: Academic Press.

Blank S., Seiter C. \& Bruce P. 2001. Resampling stats in Excel. Arlington: Resampling Stats Inc.

Bond W.J. 2016. Ancient grasslands at risk. Science 351: 120-122.

Bond W.J. \& Parr C.L. 2010. Beyond the forest edge: ecology, diversity and conservation of the grassy biomes. Biological Conservation 143: 2395-2404.

Cody M.L. 1985. Habitat selection in grassland and open-country birds, p. 107-113. In: Cody M.L. (eds.). Habitat selection in birds. Orlando: Academic Press.

Colwell R.K. 2013. EstimateS: statistical estimation of species richness and shared species from samples: user's guide and application. http:// purl.oclc.org/estimates (Accessed 16 February 2019).

Colwell R.K. \& Coddington J.A. 1994. Estimating terrestrial biodiversity through extrapolation. Philosophical Transactions of the Royal Society, Series B: Biological Sciences 345: 101-118.

Dias R.A., Bastazini V.A.G. \& Gianuca A.T. 2014. Bird-habitat associations in coastal rangelands of southern Brazil. Iheringia, Série Zoologia 104: 200-208.

Fisher R.J. \& Davis S.K. 2011. Post-fledging dispersal, habitat use, and survival of Sprague's Pipits: Are planted grasslands a good substitute for native? Biological Conservation 144: 263-271.

Fontana C.S., Dotta G., Kelm-Marques C., Repenning M., Agne C.E. \& Santos R.J. 2016. Conservation of grassland birds in south Brazil: a land management perspective. Natureza \& Conservação 14: 83-87. 
Galligan E.W., Devault T.L. \& Lima S.L. 2006. Nesting success of grassland and savanna birds on reclaimed surface coal mines of the midwestern United States. Wilson Journal of Ornithology 118: 537-546.

Gotelli N.J. \& Colwell R.K. 2001. Quantifying biodiversity: procedures and pitfalls in the measurement and comparison of species richness. Ecology Letters 4: 379-391.

Hovick T.J., Elmore R.D., Fuhlendorf S.D., Engle D.M. \& Hamilton R.G. 2015. Spatial heterogeneity increases diversity and stability in grassland bird communities. Ecological Applications 25: 662672.

ICMBio [Instituto Chico Mendes de Conservaçáo da Biodiversidade]. 2014. Instrução Normativa No. 11 de 11 de dezembro de 2014. Brasília: Diário Oficial da União.

Krebs C.J. 1999. Ecological methodology. New York: Harper and Row.

Magurran A.E. 1988. Ecological diversity and its measurement. Princeton: Princeton University Press.

McDonald J.H. 2014. Handbook of biological statistics. Baltimore: Sparky House Publishing.

Menezes L.S., Ely C.V., Lucas D.B., Silva G.H.M., Boldrini I.I. \& Overbeck G.E. 2018. Plant species richness record in Brazilian Pampa grasslands and implications. Brazilian Journal of Botany 41: 817-823.

Oksanen J., Blanchet F.G., Kindt R., Legendre P., Minchin P.R., O'Hara R.B., Gavin L. Simpson G.L., Solymos P., Stevens M.H.H. \& Wagner H. 2011. Vegan: community ecology package. http://CRAN.R-project.org/package=vegan (Access on 12 November 2017).

Overbeck G.E., Hermann J.M., Andrade B.O., Boldrini I.I., Kiehl K., Kirmer A., Koch C., Kollmann J., Meyer S.T., Müller S.C., Nabinger C., Pilger G.E., Trindade J.P.P., Vélez-Martin E., Walker E.A., Zimmermann D.G. \& Pillar V.D. 2013. Restoration ecology in Brazil: time to step out of the forest. Natureza \& Conservação 11: 92-95.
Parr C.L., Lehmann C.E., Bond W.J., Hoffmann W.A. \& Andersen A.N. 2014. Tropical grassy biomes: misunderstood, neglected, and under threat. Trends in Ecology \& Evolution 29: 205-213.

Piacentini V.Q., Aleixo A., Agne C.E., Maurício G.N., Pacheco J.F., Bravo G.A., Brito G.R.R., Naka L.N., Olmos F., Posso S., Silveira L.F., Betini G.S., Carrano E., Franz I., Lees A.C., Lima L.M., Pioli D., Schunck F., Amaral F.R., Bencke G.A., Cohn-Haft M., Figueiredo L.F.A., Straube F.C. \& Cesari E. 2015. Annotated checklist of the birds of Brazil by the Brazilian Ornithological Records Committee. Revista Brasileira de Ornitologia 23: 91-298.

Pillar V.D. \& Vélez E. 2010. Extinção dos Campos Sulinos em unidades de conservação: um fenômeno natural ou um problema ético? Natureza \& Conservação 8: 84-86.

Quinn G.P. \& Keough M.J. 2002. Experimental design and data analysis for biologists. Cambridge: Cambridge University Press.

R Core Team 2017. R: a language and environment for statistical computing. Vienna: R Foundation for Statistical Computing. http://www.R-project.org/_(Access on 12 November 2017).

Scott P.E., DeVault T.L., Bajema R.A. \& Lima S.L. 2002. Grassland vegetation and bird abundances on reclaimed midwestern coal mines. Wildlife Society Bulletin 30: 1006-1014.

Silva T.W. 2019. Comunidade de aves em áreas campestres degradadas por cultivos, em processo de restauração no Bioma Pampa, sul do Brasil. Ph.D. Thesis. PUCRS: Porto Alegre.

Silva T.W., Dotta G., Gressler D.T. \& Fontana C.S. 2015. Habitat use by grassland birds in natural areas and soybean fields in southern Brazil and Uruguay. Wilson Journal of Ornithology 127: 212-221.

Simon J.L. 1997. Resampling: the new statistics. Arlington: Resampling Stats Inc.

Zimmerman G.M., Goetz H. \& Mielke-Jr. P.W. 1985. Use of an improved statistical method for group comparisons to study effects of prairie fire. Ecology 66: 606-611.

Associate Editor: Carla S. Fontana.

\section{APPENDIX I}

Bird species recorded in natural grasslands and grasslands revegetated after mining in south Brazil.

\begin{tabular}{|c|c|c|c|c|}
\hline \multirow{2}{*}{$\begin{array}{l}\text { Family } \\
\text { Species }\end{array}$} & \multirow{2}{*}{$\begin{array}{c}\text { Grassland } \\
\text { specialization }^{\mathrm{a}}\end{array}$} & \multicolumn{2}{|c|}{ Number of records } & \multirow{2}{*}{$P$ value $^{\mathrm{b}}$} \\
\hline & & Natural & Revegetated & \\
\hline \multicolumn{5}{|l|}{ Tinamidae } \\
\hline Rhynchotus rufescens & 2 & 69 & 25 & 0.009 \\
\hline Nothura maculosa & 2 & 66 & 31 & 0.010 \\
\hline \multicolumn{5}{|l|}{ Anatidae } \\
\hline Amazonetta brasiliensis & - & 0 & 2 & \\
\hline \multicolumn{5}{|l|}{ Accipitridae } \\
\hline Elanus leucurus & 3 & 1 & 0 & \\
\hline Rupornis magnirostris & - & 0 & 1 & \\
\hline \multicolumn{5}{|l|}{ Charadriidae } \\
\hline Vanellus chilensis & 2 & 2 & 11 & 0.055 \\
\hline \multicolumn{5}{|l|}{ Columbidae } \\
\hline Columbina picui & - & 8 & 3 & \\
\hline Leptotila verreauxi & - & 0 & 1 & \\
\hline
\end{tabular}




\begin{tabular}{lccc}
\hline Family & Grassland & Number of records & Pvalue $^{\mathrm{b}}$ \\
\cline { 3 - 3 } Species & specialization $^{\mathrm{a}}$ & Natural & Revegetated
\end{tabular}

Cuculidae

Tapera naevia

8

8

Guira guira

8

4

Picidae

Colaptes campestris

Veniliornis spilogaster

Cariamidae

Cariama cristata

Thamnophilidae

- 1

40

0.002

1

0

0

6

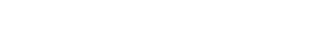

Thamnophilus caerulescens

Thamnophilus ruficapillus

Furnariidae

Synallaxis cinerascens

Synallaxis spixi

Furnarius rufus

Anumbius annumbi

Phacellodomus striaticollis

Tyrannidae

Camptostoma obsoletum

Serpophaga subcristata

Pitangus sulphuratus

Xolmis cinereus

Tyrannus savana

6

27

0

12

0.080

$\begin{array}{ll}- & \\ - & 27\end{array}$

6

\section{Vireonidae}

Cyclarhis gujanensis

\section{Hirundinidae}

Pygochelidon cyanoleuca

Troglodytidae

Troglodytes musculus

\section{Turdidae}

Turdus rufiventris

Turdus amaurochalinus

\section{Motacillidae}

Anthus lutescens

\section{Passerellidae}

Zonotrichia capensis

Ammodramus humeralis

\section{Parulidae}

Geothlypis aequinoctialis

Icteridae

Chrysomus ruficapillus

Pseudoleistes virescens
13

21

19

72

3

11

0.73

18

20

0.20

2

3

$\begin{array}{ll}- & 1 \\ - & 18 \\ - & 1 \\ 2 & 6 \\ 3 & 5\end{array}$

25

0.84

0.08

0.03

$<0.001$

$<0.001$

60

52

3

4

0

13

27

0.11

0.55

0

7

2

0

0.03

224

164

0.55

2

135

122

0.002

50

16

5

19
0

0 


\begin{tabular}{|c|c|c|c|c|}
\hline \multirow{2}{*}{$\begin{array}{l}\text { Family } \\
\text { Species }\end{array}$} & \multirow{2}{*}{$\begin{array}{c}\text { Grassland } \\
\text { specialization }^{\mathrm{a}}\end{array}$} & \multicolumn{2}{|c|}{ Number of records } & \multirow{2}{*}{$P$ value } \\
\hline & & Natural & Revegetated & \\
\hline Sturnella superciliaris & 2 & 0 & 6 & \\
\hline Agelaioides badius & - & 8 & 0 & \\
\hline Molothrus bonariensis & 3 & 62 & 0 & $<0.001$ \\
\hline \multicolumn{5}{|l|}{ Thraupidae } \\
\hline Microspingus cabanisi & - & 3 & 0 & \\
\hline Poospiza nigrorufa & 3 & 23 & 2 & 0.007 \\
\hline Sicalis flaveola & - & 73 & 4 & $<0.001$ \\
\hline Sicalis luteola & 2 & 154 & 179 & 0.33 \\
\hline Sporophila caerulescens & - & 2 & 8 & 0.15 \\
\hline Volatinia jacarina & 2 & 0 & 7 & \\
\hline Donacospiza albifrons & 2 & 87 & 11 & $<0.001$ \\
\hline Embernagra platensis & 2 & 139 & 58 & $<0.001$ \\
\hline Paroaria coronata & - & 2 & 0 & \\
\hline \multicolumn{5}{|l|}{ Fringillidae } \\
\hline Spinus magellanicus & - & 56 & 3 & $<0.001$ \\
\hline
\end{tabular}

